\title{
PENGARUH NET PROFIT MARGIN DAN DEBT TO EQUITY RATIO TERHADAP HARGA SAHAM PADA PT. ARWANA CITRAMULIA, TBK
}

\author{
1*Yeti Kusmawati, ${ }^{2}$ Denok Sunarsi, ${ }^{3}$ Sudiarto, ${ }^{4}$ Ratna Dumilah \\ Universitas Pamulang, Tangerang Selatan, Banten, Indonesia \\ *dosen02619@unpam.ac.id
}

\begin{abstract}
Abstrak
Penelitian ini bertujuan untuk mengetahui pengaruh Net Profit Margin dan Debt to Equity Ratio terhadap Harga Saham pada PT. Arwana Citramulia, Tbk Periode Tahun 2010-2019. Metode yang digunakan adalah explanatory research dengan teknik analisis menggunakan analisis statistik dengan pengujian regresi, korelasi, determinasi dan uji hipotesis. Hasil penelitian ini Net Profit Margin tidak berpengaruh signifikan terhadap harga saham sebesar $27,0 \%$, uji hipotesis diperoleh nilai Signifikansi (Sig.) 0,123 > 0,05. Debt to Equity Ratio berpengaruh signifikan terhadap harga saham sebesar 59,0\%, uji hipotesis diperoleh nilai Signifikansi (Sig.) 0,009 < 0,05. Net Profit Margin dan Debt to Equity Ratio secara simultan berpengaruh signifikan terhadap harga saham dengan persamaan regresi $\mathrm{Y}=781,144+$ 19,436X1 - 8,776X2 dan kontribusi pengaruh sebesar 67,0\%, uji hipotesis diperoleh nilai Signifikansi (Sig.) 0,021<0,05.
\end{abstract}

Kata Kunci: Net Profit Margin, Debt to Equity Ratio, Harga Saham.

\begin{abstract}
This study aims to determine the effect of Net Profit Margin and Debt to Equity Ratio on stock prices at PT. Arwana Citramulia, Tbk Period 2010-2019. The method used is explanatory research with analytical techniques using statistical analysis with regression, correlation, determination and hypothesis testing. The results of this study Net Profit Margin has no significant effect on stock prices of 27.0\%, hypothesis testing obtained a significance value (Sig.) 0.123 > 0.05. Debt to Equity Ratio has a significant effect on stock prices of 59.0\%, hypothesis testing obtained a significance value (Sig.) $0.009<0.05$. Net Profit Margin and Debt to Equity Ratio simultaneously have a significant effect on stock prices with the regression equation $Y=$ $781.144+19.436 \times 1-8,776 X 2$ and the contribution of the effect is $67.0 \%$, hypothesis testing is obtained Significance value (Sig.) $0.021<0.05$.
\end{abstract}

Keywords: Net Profit Margin, Debt to Equity Ratio, Stock Price.

\section{PENDAHULUAN}

Perekonomian pada saat sekarang selalu mengalami perubahan dan persaingan bisnis yang sangat ketat, sehingga, membuat para manajer terus meningkatkan laba perusahaannya dengan mengembangkan dan menjalankan perusahaannya secara optimal. Persaingan bisnis tidak dapat dihindarkan antara perusahaan yang satu dengan perusahaan yang lainnya. Manajer yang ingin terus menjaga kelangsungan hidup perusahaannya harus memaksimalkan keuntungan dari tahun ke tahun. Setiap perusahaan yang akan berekspansi, perusahaan tersebut membutuhkan modal, dan modal terhadap tersebut dapat berasal dari utang maupun ekuitas.

Harga saham yang mengalami kenaikan mempunyai dampak baik pada modal perusahaan karena dapat meningkatkan nilai saham, sebaliknya akan berdampak buruk pada modal perusahaan karena modal tersebut tidak akan bertambah dan akan berhenti karena saham tersebut tidak laku dan banyak investor ingin menjual sahamnya. Sehingga transaksi pasar menjadi lemah karena harga saham yang mahal dan kemampuan investor untuk membeli saham dengan harga tinggi yang terbatas. Maka dari itu setiap Perusahaan akan selalu berusaha meningkatkan atau sedikitnya mempertahankan nilai saham yang di raih pada setiap tahunnya. Menurut Jogiyanto (2008:167) "Harga suatu saham yang terjadi di pasar bursa pada saat tertentu yang ditentukan oleh pelaku pasar dan ditentukan oleh permintaan dan penawaran saham yang bersangkutan di pasar modal"

Rasio pertama yang diperkirakan mempengaruhi harga saham yaitu Net Profit Margin (NPM) merupakan rasio antara laba bersih setelah pajak atau net income after tax 
(NIAT) dengan net sales. Semakin besar nilai NPM menunjukkan tingginya kemampuan perusahaan dalam menghasilkan laba bersih. Menurut Kasmir (2012:199) Net Profit Margin adalah "Salah satu rasio yang digunakan untuk mengukur margin laba atas penjualan. Cara pengukuran rasio ini adalah dengan membandingkan laba bersih setelah pajak dengan penjualan bersih".

Perusahaan yang mampu menghasilkan keuntungan akan mempengaruhi investor atau calon investor untuk melakukan investasi. Investor akan bersedia membeli saham dengan harga lebih tinggi apabila memperkirakan tingkat NPM perusahaan naik, dan sebaliknya investor tidak bersedia membeli saham dengan harga tinggi apabila nilai NPM perusahaan rendah

Rasio kedua yang diperkirakan mempengaruhi harga saham yaitu Debt To Equity Ratio dimana rasio ini disebut juga sebagai rasio yang melihat perbandingan hutang perusahaan, yaitu diperoleh dari perbandingan total hutang dibagi total aset. Semakin rendah semakin baik karena aman bagi kreditor saat likuidasi. Bagi perusahaan, sebaiknya besarnya hutang tidak boleh melebihi modal sendiri agar beban tetapnya tidak terlalu tinggi. Menurut Brigham dan Houston (2006:104) "DER yang rendah akan meningkatkan respon positif dari pasar dan akan semakin baik kemampuan perusahaan dalam membayar kewajiban jangka panjang karena risiko yang ditimbulkan dari penggunaan pendanaan yang bersumber dari hutang akan berkurang, sehingga saham naik. Oleh karena itu, DER memiliki pengaruh negatif terhadap harga saham".

PT. Arwana Citramulia Tbk adalah perusahaan keramik yang bersifat publik yang terdaftar dalam Bursa Efek Indonesia dengan kode saham "ARNA". Sebagai salah satu dari enam industri keramik terbesar dalam pasar bahan bangunan pada skala nasional yang bertekad menunjukkan kreasi dan inovasi, serta mampu memberikan kontribusi bagi lingkungan sekitar dan negeri ini. Berikut adalah data kuantitatif sehubungan dengan Net Profit Margin (NPM), Debt To Equity Ratio (DER) dan harga saham PT. Arwana Citramulia Tbk pada periode tahun 2010 - 2019.

Tabel 1. Net Profit Margin (NPM), Debt To Equity Ratio (DER) dan harga saham PT. Arwana

Citramulia Tbk. Periode 2010 - 2019

\begin{tabular}{|c|c|c|c|}
\hline Tahun & NPM (\%) & DER (\%) & Harga Saham (Rp penuh) \\
\hline 2010 & 9,52 & 112,08 & 70 \\
\hline 2011 & 10,40 & 72,09 & 90 \\
\hline 2012 & 14,25 & 54,98 & 410 \\
\hline 2013 & 16,77 & 47,72 & 850 \\
\hline 2014 & 16,25 & 38,03 & 870 \\
\hline 2015 & 5,51 & 59,91 & 500 \\
\hline 2016 & 6,04 & 62,77 & 520 \\
\hline 2017 & 7,05 & 55,56 & 344 \\
\hline 2018 & 8,02 & 50,73 & 420 \\
\hline 2019 & 10,12 & 52,89 & 432 \\
\hline
\end{tabular}

Sumber : IDX (2020)

Kondisi perkembangan Net Profit

Margin (NPM), Debt To Equity Ratio

(DER) dan Harga Saham PT. Arwana

Citramulia Tbk. Periode 2010 - 2019 di atas jika dibuat grafik maka akan terlihat sebagai berikut:

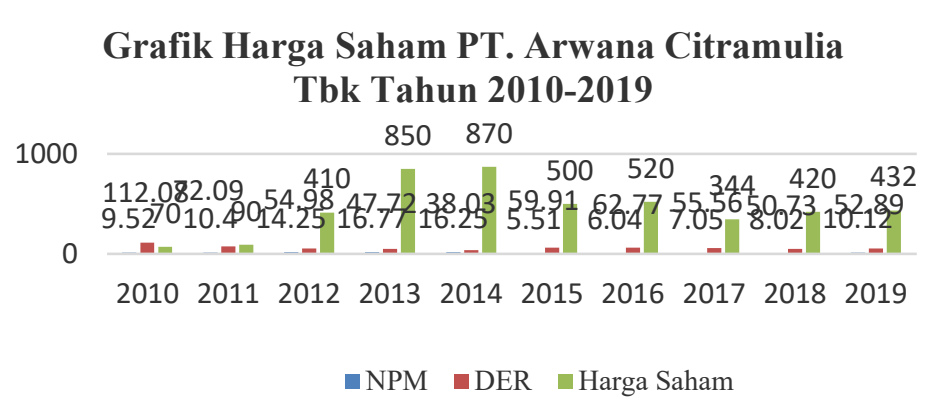

Gambar 1. Net Profit Margin (NPM), Debt To Equity Ratio (DER) dan Harga Saham 
Pada tahun 2019 harga saham PT. Arwana Citramulia Tbk jatuh pada angka 432 dengan Net Profit Margin (NPM) sebesar 10,12\%, diiringi rasio Debt To Equity Ratio (DER) sebesar 52,89\%. Pada tahun 2014 harga saham naik dan berada pada posisi tertinggi untuk periode 2010-2019 ini, dengan harga saham di angka 870, sehingga NPM dapat dicapai pada angka 16,25\% dan DER berada pada posisi terendah yaitu diangka 38,03\%.

Berdasarkan pemaparan dan melihat data empirik yang ada, maka penulis tertarik untuk melakukan penelitian dengan judul "Pengaruh Net Profit Margin (NPM) Dan Debt to Equity Ratio (DER) Terhadap Harga Saham pada PT. Arwana Citramulia, Tbk Periode Tahun 2010-2019".

\section{TINJAUAN PUSTAKA}

\section{Net Profit Margin}

Net Profit Margin (NPM) menghitung sejauh mana perusahaan menghasilkan laba bersih pada tingkat penjualan tertentu. Rasio ini bisa diinterpretasikan juga sebagai kemampuan perusahaan menekan biayabiaya (ukuran efisiensi) diperusahaan pada periode tertentu. Menurut Hanafi, Mamduh dan Abdul Halim (2012:81) "Profit Margin yang tinggi menandakan kemampuan perusahaan menghasilkan laba yang tinggi pada tingkat penjualan tertentu. Profit Margin yang rendah menandakan penjualan yang terlalu rendah untuk tingkat biaya tertentu, atau biaya yang terlalu tinggi untuk tingkat penjualan tertentu, atau kombinasi dari kedua hal tersebut". Secara umum rasio yang rendah bisa menunjukkan ketidakefisienan manajemen. Rasio ini cukup bervariasi dari industri ke industri. Adapun Rasio Net Profit Margin bisa dihitung sebagai berikut:

Net Profi Margin (NPM): Laba Bersih Setelah Pajak x 100\%

Penjualan Bersih

\section{Debt to Equity Ratio}

Menurut Ang, Marietta (2012) “DER merupakan rasio yang digunakan untuk mengukur tingkat leverage terhadap shareholders yang dimiliki perusahaan". Faktor ini mencerminkan kemampuan perusahaan dalam memenuhi seluruh kewajibannya yang ditunjukkan oleh beberapa bagian modal sendiri yang digunakan untuk membayar hutang. Semakin besar rasio ini menunjukkan semakin besar kewajiban suatu perusahaan dan rasio yang rendah mengartikan kemampuan perusahaan memenuhi seluruh kewajibannya yang tinggi.

$$
\text { DER }=\frac{\text { Total hutang }}{\text { Total Modal Sendiri }} \times 100 \%
$$

\section{Harga Saham}

Total Modal Sendiri

Variabel terikat dalam penelitian ini adalah harga saham, harga yang terbentuk dari permintaan dan penawaran suatu produk pada tingkat periode penjualan tertentu. Menurut Fahmi (2012:81) "Saham merupakan salah satu instrument pasar modal yang paling banyak diminati oleh investor, karena mampu memberikan tingkat pengembalian yang menarik. Saham adalah kertas yang tercantum dengan jelas nilai nominal, nama perusahaan, dan diikuti dengan hak dan kewajiban yang telah dijelaskan kepada setiap pemegangnya".

\section{METODE}

Dalam penelitian ini yang dijadikan populasi adalah laporan keuangan (yang sudah dibuat berupa data panel) PT. Arwana Citramulia, Tbk Tahun 2010 - 2019. Sampel dalam penelitian ini 10 tahun laporan keuangan berupa data panel PT. Arwana Citramulia, Tbk Tahun 2010 - 2019. Jenis penelitian yang dipakai adalah kuantitatif, dimana tujuannya adalah untuk mengetahui pengaruh antara variabel bebas terhadap variabel terikat baik parsial maupun simultan Dalam menganalisis data digunakan uji instrumen, uji asumsi klasik, regresi, koefisien korelasi, koefisien determinasi dan uji hipotesis.

\section{HASIL DAN PEMBAHASAN}

\section{Analisis Deskriptif}

Pada pengujian ini digunakan untuk mengetahui skor minimum dan maksimum, mean score dan standar deviasi dari masing-masing variabel. Adapun hasilnya sebagai berikut: 
Tabel 2. Hasil Analisis Descriptive Statistics

Descriptive Statistics

$\mathrm{N}$ Minimum Maximum Mean Std. Deviation

\begin{tabular}{|lr|r|r|r|r|r|}
\hline Net Profit Margin (X1) & 10 & 5.51 & 16.77 & 10.393 & 4.086 \\
\hline Debt to Equity Ratio (X2) & 10 & 38.03 & 112.08 & 60.676 & 20.211 \\
\hline Harga Saham (Y) & 10 & 70.00 & 870.00 & 450.600 & 264.964 \\
\hline Valid N (listwise) & 10 & & & & \\
\hline
\end{tabular}

Nilai Net Profit Margin diperoleh persentase minimum sebesar $5,51 \%$ dan persentase maximum $16,77 \%$ dengan ratarata 10,39\% dengan standar deviasi 4,086. Nilai Debt to Equity Ratio diperoleh persentase minimum sebesar 38,03\% dan persentase maximum $112,08 \%$ dengan rata-rata $60,67 \%$ dengan standar deviasi 20,211 .

Nilai Harga Saham diperoleh nilai minimum sebesar 70,00 dan nilai maximum 870,00 dengan rata-rata 450,600 dengan standar deviasi 264,964.

\section{Analisis Kuantitatif}

Pada analisis ini dimaksudkan untuk mengetahui pengaruh variabel independen terhadap variabel dependen. Adapun hasil pengujian sebagai berikut:

\section{a. Analisis Regresi Linier Berganda}

Uji regresi ini dimaksudkan untuk mengetahui perubahan variabel dependen jika variabel independen mengalami perubahan. Adapun hasil pengujiannya sebagai berikut:

Tabel 3. Hasil Pengujian Regresi Linier Berganda

\begin{tabular}{|c|c|c|c|c|c|}
\hline & Coefficie & nts $\mathbf{a}^{\mathrm{a}}$ & & & \\
\hline & $\begin{array}{l}\text { Unstan } \\
\text { Coeff }\end{array}$ & $\begin{array}{l}\text { ardized } \\
\text { cients }\end{array}$ & $\begin{array}{l}\text { Standardized } \\
\text { Coefficients }\end{array}$ & & \\
\hline Model & B & $\begin{array}{l}\text { Std. } \\
\text { Error }\end{array}$ & Beta & $t$ & Sig. \\
\hline 1 (Constant) & 781.114 & 281.197 & & 2.778 & .027 \\
\hline Net Profit Margin (X1) & 19.436 & 14.908 & .300 & 1.304 & .234 \\
\hline Debt to Equity Ratio (X2) & -8.776 & 3.014 & -.669 & -2.912 & .023 \\
\hline
\end{tabular}

a. Dependent Variable: Harga Saham (Y)

Berdasarkan hasil pengujian pada tabel di atas, diperoleh persamaan regresi $\mathrm{Y}=781,144+19,436 \mathrm{X} 1$ 8,776X2. Dari persamaan tersebut dijelaskan sebagai berikut:

1) Konstanta sebesar 781,144 diartikan jika Net Profit Margin dan Debt to Equity Ratio tidak ada, maka telah terdapat nilai Harga Saham sebesar 781,144 point.

2) Koefisien regresi Net Profit Margin sebesar 19,436, angka ini positif artinya setiap ada peningkatan $\mathrm{Net}$ Profit Margin sebesar 19,436 maka Harga Saham juga akan mengalami peningkatan sebesar 19,436 point. Tabel 4. Hasil Pengujian Koefisien Korelasi Net Profit Margin Terhadap Harga Saham.

Correlations $^{\mathbf{a}}$

Net Profit Margin (X1) Harga Saham (Y)

\begin{tabular}{llr|r} 
& \multicolumn{2}{c}{ Correlations } \\
& \multicolumn{2}{c}{ Net Profit Margin (X1) } & Harga Saham (Y) \\
\hline \multirow{2}{*}{ Net Profit Margin (X1) } & Pearson Correlation & 1 & .520 \\
\cline { 2 - 4 } & Sig. (2-tailed) & & .123 \\
\hline Harga Saham (Y) & Pearson Correlation & .520 & 1 \\
\cline { 2 - 4 } & Sig. (2-tailed) & .123 & \\
\hline
\end{tabular}

3) Koefisien regresi Debt to Equity Ratio sebesar -8,776, angka ini negatif artinya setiap ada penurunan Debt to Equity Ratio sebesar -8,776 maka Harga Saham juga akan mengalami penurunan 4) sebesar $-8,776$ point.

\section{b. Analisis Koefisien Korelasi}

Analisis koefisien korelasi dimaksudkan untuk mengetahui tingkt kekuatan hubungan dari variabel independen terhadap variabel dependen baik secara parsial maupun simultan. Adapun hasil pengujian sebagai berikut: 
a. Listwise $\mathrm{N}=10$

Berdasarkan hasil pengujian diperoleh nilai korelasi sebesar 0,520 hubungan yang sedang terhadap nilai artinya Net Profit Margin memiliki harga saham.

Tabel 5. Hasil Pengujian Koefisien Korelasi Debt to Equity Ratio Terhadap Harga Saham. Correlations ${ }^{b}$

\begin{tabular}{llr|r} 
& & $\begin{array}{c}\text { Debt to Equity } \\
\text { Ratio (X2) }\end{array}$ & Harga Saham (Y) \\
\hline Debt to Equity Ratio (X2) & Pearson Correlation & 1 & $-.768^{* *}$ \\
\cline { 2 - 4 } & Sig. (2-tailed) & & .009 \\
\hline Harga Saham (Y) & Pearson Correlation & $-.768^{* *}$ & 1 \\
\cline { 2 - 4 } & Sig. (2-tailed) & .009 & \\
\hline
\end{tabular}

**. Correlation is significant at the 0.01 level (2-tailed).

b. Listwise $\mathrm{N}=10$

Berdasarkan hasil pengujian diperoleh nilai korelasi sebesar $-0,768$ artinya Debt to Equity Ratio memiliki hubungan yang negatif kuat terhadap nilai harga saham.

Tabel 6. Hasil Pengujian Koefisien Korelasi Net Profit Margin dan Debt to Equity Ratio secara simultan Terhadap Harga Saham.

\section{Model Summary}

\begin{tabular}{|c|c|c|c|c|}
\hline \\
\hline Mod & $\mathrm{R}$ & R Square & $\begin{array}{l}\text { Adjusted R } \\
\text { Square }\end{array}$ & $\begin{array}{l}\text { Std. Error of the } \\
\text { Estimate }\end{array}$ \\
\hline 1 & $.819^{a}$ & .670 & .576 & 172.57558 \\
\hline
\end{tabular}

a. Predictors: (Constant), Debt to Equity Ratio (X2), Net Profit Margin (X1)

Berdasarkan hasil pengujian diperoleh nilai korelasi sebesar 0,819 artinya Net Profit

Margin dan Debt to Equity Ratio

secara simultan memiliki hubungan yang sangat kuat terhadap nilai harga

c. Analisis Koefisien Determinasi saham.

Analisis koefisien determinasi dimaksudkan untuk mengetahui besarnya persentase pengaruh dari variabel independen terhadap variabel dependen baik secara parsial maupun simultan. Adapun hasil pengujian sebagai berikut:

Tabel 7. Hasil Pengujian Koefisien Determinasi Net Profit Margin Terhadap Harga Saham.

Model Summary

\begin{tabular}{l|r|rr|r} 
Model & $\mathrm{R}$ & R Square & $\begin{array}{c}\text { Adjusted R } \\
\text { Square }\end{array}$ & $\begin{array}{c}\text { Std. Error of the } \\
\text { Estimate }\end{array}$ \\
\hline 1 & $.520^{\mathrm{a}}$ & .270 & .179 & 240.05110 \\
\hline
\end{tabular}

a. Predictors: (Constant), Net Profit Margin (X1)

Berdasarkan hasil pengujian

memiliki kontribusi pengaruh sebesar diperoleh nilai determinasi sebesar $27,0 \%$ terhadap nilai harga saham. 0,270 artinya Net Profit Margin

Tabel 8. Hasil Pengujian Koefisien Determinasi Debt to Equity Ratio Terhadap Harga Saham.

Model Summary

\begin{tabular}{l|r|rr|c} 
Model & R & R Square & $\begin{array}{c}\text { Adjusted R } \\
\text { Square }\end{array}$ & $\begin{array}{c}\text { Std. Error of the } \\
\text { Estimate }\end{array}$ \\
\hline 1 & $.768^{\mathrm{a}}$ & .590 & .539 & 179.96544 \\
\hline
\end{tabular}

a. Predictors: (Constant), Debt to Equity Ratio (X2)

Berdasarkan hasil pengujian diperoleh nilai determinasi sebesar
0,590 artinya Debt to Equity Ratio memiliki kontribusi pengaruh sebesar 
$59,0 \%$ terhadap nilai harga saham.

Tabel 9. Hasil Pengujian Koefisien Determinasi Net Profit Margin dan Debt to Equity Ratio Terhadap Harga Saham.

Model Summary

\begin{tabular}{|c|c|c|c|c|}
\hline \multicolumn{5}{|c|}{ Moder sumary } \\
\hline Model & $\mathrm{R}$ & R Square & $\begin{array}{l}\text { Adjusted R } \\
\text { Square }\end{array}$ & $\begin{array}{l}\text { Std. Error of the } \\
\text { Estimate }\end{array}$ \\
\hline 1 & $.819^{a}$ & .670 & .57 & $172.575 \mathrm{~s}$ \\
\hline
\end{tabular}

a. Predictors: (Constant), Debt to Equity Ratio (X2), Net Profit Margin (X1)

Berdasarkan hasil pengujian diperoleh nilai determinasi sebesar 0,670 artinya Net Profit Margin dan Debt to Equity Ratio secara simultan memiliki kontribusi pengaruh sebesar $67,0 \%$ terhadap nilai harga saham, sedangkan sisanya sebesar $33,0 \%$ dipengaruhi faktor lain.

\section{d. Uji Hipotesis}

Uji hipotesis Parsial (Uji t)

Pengujian hipotesis dengan uji $t$ digunakan untuk mengetahui hipotesis parsial mana yang diterima.

Hipotesis pertama: Terdapat pengaruh yang signifikan antara Net Profit Margin terhadap nilai harga saham.

Tabel 10. Hasil Uji Hipotesis Net Profit Margin Terhadap Harga Saham.

\section{Coefficients ${ }^{\mathrm{a}}$}

Unstandardized Standardized

Coefficients Coefficients

\begin{tabular}{ll|r|r|r|r} 
Model & \multicolumn{1}{c|}{ B } & Std. Error & Beta & \multicolumn{1}{c}{$\mathrm{t}$} & \multicolumn{1}{c}{ Sig. } \\
\hline 1 & 100.166 & 217.209 & & .461 & .657 \\
\hline $\begin{array}{l}\text { (Constant) } \\
\begin{array}{l}\text { Net Profit Margin } \\
(\mathrm{X} 1)\end{array}\end{array}$ & 33.718 & 19.582 & .520 & 1.722 & .123 \\
\hline
\end{tabular}

a. Dependent Variable: Harga Saham (Y)

Berdasarkan hasil pengujian pada tabel di atas, diperoleh nilai Signifikansi (Sig.) 0,123 > 0,05, dengan demikian hipotesis pertama yang Tabel 11. Hasil Uji Hipotesis Debt to Equity Ratio Terhadap Harga Saham.

\section{Coefficients}

Unstandardized

Coefficients diajukan bahwa terdapat pengaruh yang signifikan atara Net Profit Margin terhadap harga saham ditolak, atau ada pengaruhnya namun negatif.

\begin{tabular}{|c|c|c|c|c|c|}
\hline \multirow[b]{2}{*}{ Model } & \multicolumn{2}{|c|}{$\begin{array}{l}\text { Coefficients }^{\mathbf{a}} \\
\text { Unstandardized } \\
\text { Coefficients }\end{array}$} & \multirow{2}{*}{$\begin{array}{c}\text { Standardized } \\
\text { Coefficients } \\
\text { Beta }\end{array}$} & \multirow[b]{2}{*}{$\mathrm{t}$} & \multirow[b]{2}{*}{ Sig. } \\
\hline & $\mathrm{B}$ & Std. Error & & & \\
\hline 1 (Constant) & 1061.560 & 188.868 & & 5.621 & .000 \\
\hline Debt to Equity Ratio (X2) & -10.069 & 2.968 & -.768 & -3.393 & .009 \\
\hline
\end{tabular}

a. Dependent Variable: Harga Saham (Y)

Berdasarkan hasil pengujian pada tabel di atas, diperoleh nilai Signifikansi (Sig.) 0,009 < 0,05, dengan demikian hipotesis kedua yang diajukan bahwa terdapat pengaruh yang signifikan atara Debt to Equity Ratio terhadap harga saham diterima.

\section{Uji Hipotesis Simultan (Uji F)}

Pengujian hipotesis dengan uji $\mathrm{F}$ digunakan untuk mengetahui hipotesis simultan yang mana yang diterima. Hipotesis ketiga Terdapat pengaruh yang signifikan antara Net Profit Margin dan Debt to Equity Ratio terhadap Harga Saham. 
Tabel 12. Hasil Uji Hipotesis Net Profit Margin dan Debt to Equity Ratio Terhadap Harga Saham.

ANOVA $^{\mathrm{a}}$

\begin{tabular}{ll|r|r|r|r|r}
\multicolumn{1}{l}{ Model } & Sum of Squares & df & Mean Square & F & \multicolumn{1}{c}{ Sig. } \\
\hline \multirow{2}{*}{1} & Regression & 423380.078 & 2 & 211690.039 & 7.108 & $.021^{\text {b }}$ \\
\cline { 2 - 7 } & Residual & 208476.322 & 7 & 29782.332 & & \\
\cline { 2 - 7 } & Total & 631856.400 & 9 & & & \\
\hline
\end{tabular}

a. Dependent Variable: Harga Saham (Y)

b. Predictors: (Constant), Debt to Equity Ratio (X2), Net Profit Margin (X1)

Berdasarkan hasil pengujian pada tabel di atas, diperoleh nilai Signifikansi (Sig.) 0,021<0,05, dengan demikian hipotesis ketiga yang diajukan bahwa terdapat pengaruh yang signifikan atara Net Profit Margin dan Debt to Equity Ratio secara bersama-sama terhadap harga saham diterima.

\section{Pembahasan Hasil Penelitian}

\section{Pengaruh Net Profit Margin Terhadap Harga Saham}

Net Profit Margin berpengaruh signifikan terhadap harga saham dengan korelasi sebesar 0,520 atau memiliki hubungan yang sedang dengan kontribusi pengaruh sebesar 27,0\%. Pengujian hipotesis diperoleh nilai nilai Signifikansi (Sig.) 0,123 > 0,05. Dengan demikian hipotesis pertama yang diajukan bahwa terdapat berpengaruh signifikan antara Net Profit Margin terhadap harga saham ditolak.

\section{Pengaruh Debt to Equity Ratio Terhadap Harga Saham}

Debt to Equity Ratio berpengaruh signifikan terhadap Harga Saham dengan korelasi sebesar $-0,768$ atau memiliki hubungan yang negatif kuat dengan kontribusi pengaruh sebesar 59,0\%. Pengujian hipotesis diperoleh nilai Signifikansi (Sig.) 0,009<0,05. Dengan demikian hipotesis kedua yang diajukan bahwa terdapat berpengaruh signifikan antara Debt to Equity Ratio terhadap harga saham diterima.

\section{Pengaruh Net Profit Margin dan Debt to Equity Ratio Terhadap Harga Saham}

Net Profit Margin dan Debt to Equity

Ratio berpengaruh signifikan terhadap Harga Saham dengan diperoleh persamaan regresi $\mathrm{Y}=781,144+$ 19,436X1 + -8,776X2, nilai korelasi sebesar 0,819 atau memiliki hubungan yang sangat kuat dengan kontribusi pengaruh sebesar $67,0 \%$ sedangkan sisanya sebesar $33,0 \%$ dipengaruhi faktor lain. Pengujian hipotesis diperoleh nilai Signifikansi (Sig.) 0,021<0,05. Dengan demikian hipotesis ketiga yang diajukan bahwa terdapat berpengaruh signifikan antara Net Profit Margin dan Debt to Equity Ratio terhadap harga saham diterima.

\section{PENUTUP}

\section{Simpulan}

1. Net Profit Margin berpengaruh signifikan terhadap Harga Saham dengan kontribusi pengaruh sebesar 27,0\%. Uji hipotesis diperoleh nilai Signifikansi (Sig.) 0,123 > 0,05 .

2. Debt to Equity Ratio berpengaruh signifikan terhadap Harga Saham dengan kontribusi pengaruh sebesar 59,0\%. Uji hipotesis diperoleh nilai Signifikansi (Sig.) $0,009<0,05$.

3. Net Profit Margin dan Debt to Equity Ratio berpengaruh signifikan terhadap Harga Saham dengan kontribusi pengaruh sebesar $67,0 \%$ sedangkan sisanya sebesar $33,0 \%$ dipengaruhi faktor lain. Uji hipotesis diperoleh nilai Signifikansi (Sig.) $0,021<0,05$.

\section{Saran}

1. Pengaruh variable net profit margin terhadap harga saham adalah sebesar $27,0 \%$, pengaruh ini positif namun tidak signifikan. Hal ini masih dapat diperbaiki dengan meningkatkan penjualan bersih dan keuntungan yang maksimal guna meningkatkan jumlah uang yang diperoleh sehingga akan meningkatkan prosentase keuntungan

2. Pengaruh variable debt to equity ratio 
terhadap harga saham adalah sebesar $59,0 \%$, pengaruh ini positif. Hal ini masih dapat diperbaiki dengan mengupayakan mempercepat kewajiban lancarnya dengan memperhitungkan siklus perputaran uang yang digunakan sehingga akan mampu menambah struktur modal dengan baik.

3. Pengaruh variable net profit margin dan Debt to equity ratio terhadap harga saham adalah sebesar 67,0\%. Hal ini menunjukkan bahwa kondisi dari masingmasing variable bebas harus ditingkatkan secara signifikan. Oleh karenanya disarankan kepada penelitian berikutnya agar melakukan penelitian yang relevan dengan cara menambah 107ariable lainnya.

\section{DAFTAR PUSTAKA}

Agus, Sartono. 2008. Manajemen Keuangan Teori dan Aplikasi Edisi Empat, Yogyakarta: BPFE.

Alexandri, Moh. Benny. 2008. Manajemen Keuangan Bisnis. Cetakan Ke satu. Bandung, Alfabeta.

Arikunto dan Suharsimi, 2010, "Prosedur Penelitian Suatu Pendekatan Praktek", PT. Rineka Cipta, Jakarta.

Bambang Riyanto, "Dasar-Dasar Pembelanjaan Perusahaan", Edisi keempat, Cetakan Kedelapan, Penerbit BPFE, Yogyakarta, 2009.

Brigham, Eugene F dan Houston. 2006. Fundamental of Financial Management: Dasar-Dasar Manajemen Keuangan. Edisi 10. Jakarta: Salemba Empat

Darsono, 2006, "Manajemen Keuangan Pendekatan Praktis", Diaudit Media, Jakarta.

Fendi Hudaya Ramadhani (2017). Pengaruh Debt To Equity (DER), Return On Equity (ROE) Dan Net Profit Margin (NPM) Terhadap Harga Saham Perusahaan Sektor Pertambangan Yang Terdaftar di Bursa Efek Indonesia Periode 20112015. Jurnal Profita, Edisi 8, Hal.1-13

Frendy Sondakh, dkk (2015). Current Ratio, Debt To Equirt Ratio, Return On Asset dan Return On Equity Pengaruhnya Terhadap Harga Saham Pada Indeks $L Q$ 45 Di BEI Periode 2010-2014. Jurnal $E M B A$, Vol. 3 No. 2 Hal. 749 - 756
Haque, M. G., Nurjaya, N., Affandi, A., Erlangga, H., \& Sunarsi, D. (2021). Micro Financial Sharia Non-bank Strategic Analysis: a Study at BMT Beringharjo, Yogyakarta. Budapest International Research and Critics Institute (BIRCI-Journal): Humanities and Social Sciences, 4(2), 1677-1686.

Hidayat, A., \& Sunarsi, D. (2020). FaktorFaktor Yang Mempengaruhi Dana Pihak Ketiga Dan Dampaknya Terhadap Profitabilitas (Survey Pada Bpr Syariah Di Jawa Barat Tahun 2014-2017). Jurnal Proaksi, 7(1), 54-65.

Horne, Van dan Wachowichz, 2005, "PrinsipPrinsip Manajemen Keuangan", Edisi Bahasa Indonesia, Salemba Empat, Jakarta.

Jogiyanto. 2008. Metodologi Penelitian Sistem Informasi. CV. Andi Offset. Yogyakarta

Kasmir, 2012 "Pengantar Manajemen Keuangan", Edisi Pertama, Cetakan kedua, Penerbit Prenada Media, Jakarta.

Kasmir. 2013. Analisis Laporan Keuangan. Rajawali Pers: Jakarta

Munawir, 2009 "Analisa Laporan Keuangan", Cetakan keempat, Penerbit Liberty, Yogyakarta.

Muslimat, A., Muhsin, H., Wahid, H. A., Yulistiana, I., Sunarsi, D., Dewi, K., ... \& Ilham, D. (2021). Develop Technology Based Multimedia For Indonesian Teachers. Journal of Contemporary Issues in Business and Government, 27(1), 1871-1882.

Purwanti, Y. (2021). The Influence Of Digital Marketing \& Innovasion On The School Performance. Turkish Journal of Computer and Mathematics Education (TURCOMAT), 12(7), 118-127.

Muslimat, A. (2021). Masa Depan Kampus Merdeka \& Merdeka Belajar: Sebuah Bunga Rampai Dosen. Bintang Visitama Publisher.

Nurjaya, N., Affandi, A., Ilham, D., Jasmani, J., \& Sunarsi, D. (2021). Pengaruh Kompetensi Sumber Daya Manusia Dan Kemampuan Pemanfaatan Teknologi Terhadap Kinerja Aparatur Desa Pada Kantor Kepala Desa Di Kabupaten Gunungkidul, Yogyakarta. JENIUS 
(Jurnal Ilmiah Manajemen Sumber Daya Manusia), 4(3), 332-346.

Nofiana, L., \& Sunarsi, D. (2020). The Influence of Inventory Round Ratio and Activities Round Ratio of Profitability (ROI). JASa (Jurnal Akuntansi, Audit dan Sistem Informasi Akuntansi), 4(1), 95103.

Noryani, Y. B. G., Sari, W. I., Rosini, I., Munadjat, B., Sunarsi, D., \& Mahnun Mas' adi, G. (2020). Did ISO 45001, ISO 22000, ISO 14001 and ISO 9001 Influence Financial Performance? Evidence from Indonesian Industries. PalArch's Journal of Archaeology of Egypt/Egyptology, 17(7), 6930-6950.

Novia Kristanti dan Sutono (2016). Pengaruh Earning Per Share, Return on Equity Terhadap Harga Saham Pada Perusahaan Food and Beverages Yang Terdaftar di Bursa Efek Indonesia. Jurnal Dharma Ekonomi, No.44 Th: XXIII, Hal. 65-73

Nuryani, Y., \& Sunarsi, D. (2020). The Effect of Current Ratio and Debt to Equity Ratio on Deviding Growth. JASa Uurnal Akuntansi, Audit dan Sistem Informasi Akuntansi), 4(2), 304-312.

Popy Ambarwati, dkk (2019). PENGARUH NET PROFIT MARGIN (NPM) DAN RETURN ON EQUITY (ROE) TERHADAP HARGA SAHAM, Business Management and enterpreneur ship journal, vol.1 no.2, Hal. 100-119

Pujiati, H., Sunarsi, D., Affandi, A., \& Anggraeni, N. (2021). Effect of ISO 9001: 2015 Quality Management
Implementation in Education on School Performance. Journal of Contemporary Issues in Business and Government, 27(1), 1848-1855.

Rondonuwu Ester, dkk (2017). Pengaruh Current Ratio, Net Profit Margin Dan Earning Per Share Terhadap Harga Saham Di Bursa Efek Indonesia. Jurnal Riset Akuntansi Going Concern, Vol.12 No.2 Hal. 204-212

Sartono, 2010, "Manajemen Keuangan Toeri dan Aplikasi", Edisi keempat, Penerbit BPFE-Yogyakarta.

Sugiyono, 2008. Metode Penelitian Kuantatif Kualitatif dan R \& D. Bandung: Alfabeta

Sugiyono, 2014, "Metode Penelitian Kuantitatif Kualitatif dan $R$ \& D", Penerbit CV. Alfabeta, Bandung.

Suharsimi Arikunto, 2010, "Prosedur Penelitian Suatu Pendekatan Praktek", PT. Rineka Cipta, Jakarta.

Suhartono, A., Jati, W., \& Sunarsi, D. (2019). Pengaruh Earning Per Share Dan Return On Asset Terhadap Harga Saham Pada PT. Bank Negara Indonesia Tbk Periode 2009-2018. Jurnal Manajemen, Bisnis dan Organisasi (JUMBO), 3(3), 182-194.

Susilo, Agus. 2009. "Pengaruh Pergerakan Rasio Profitabilitas Emiten Terhadap Perubahan Harga Saham (studi Kasus Perusahaan Perbankan Yang Terdaftar Di Bursa Efek Indonesia Tahun 20052007"), Universitas Muhammadiyah Surakarta. 